\title{
THE CAPACITY IMPROVEMENT OF EGG DUCK FARMERS IN DESA KOLAM THROUGH ENHANCING THEIR FINANCIAL MANAGEMENT AND ENTREPRENEURSHIP SKILL
}

\author{
Pasca Dwi Putra \\ Department of Bussiness Administration Education, Faculty of Economics, Medan State University \\ *Correspondence Author: sgacenter@gmail.com
}

\begin{abstract}
The purpose of community service is for training and counseling to duck farmers to plan and market their business to be better and can compete in the business world. In addition, the importance of financial management and entrepreneurship helps the farmers to plan their finances and marketing so that people can know the potential they have and see opportunities to develop the livestock business. The results of this dedication show that training and counseling of financial and entrepreneurial management helps farmers in financial planning such as feed and maintenance costs incurred, calculate the reasonable selling price of eggs, and plan future activities in developing the livestock business. Due to background education of farmers not from financial, so deep enough approach is required in explaining financial management and entrepreneurship as well as simple submission so that farmers can more easily understand the application of financial management concepts and entrepreneurship in the business world.
\end{abstract}

Keywords: Financial Management, Entrepreneurship, Duck Farmers, Desa Kolam

\section{INTRODUCTION}

Sluggish economic growth now requires governments to seek ways to improve people's lives by working with communities to create a working world. The increasing number of unemployed due to limited employment makes it a problem for countries to find solutions in creating creative jobs and generate income for communities and sources of income for tax-derived countries.

The importance of building a business in the community as an effort to reduce the number of unemployed in Indonesia. One of them is in Desa Kolam sub district of Percut Sei Tuan, Deli Serdang district in Province of North Sumatera. Desa Kolam is one of the villages found in Deli Serdang District which has an area of $5.98 \mathrm{Km} 2$ with a population of 15,326 is a potential area in improving the economy of the community. Desa Kolam is located in sub district of Percut Sei Tuan which has an area of $190.79 \mathrm{Km} 2$ or about $3.13 \%$ of the total area. (https://deliserdangkab.bps.go.id/linkTabelStatis/view/id/16)

Desa Kolam is one of the villages whose majority is surrounded by plantations so that the main livelihoods of the surrounding community are farming, raising, gardening. But there are still many areas of the village that have not been fully utilized by the community to build its territory and economy. If seen, the potential that is still not widely utilized by the surrounding community that is poultry breeding, especially ducks. If we see, Desa Kolam has a great potential in breeding ducks where there are many farms and plantations that are a source of food for the duck. This can be used as employment for the community to be able to suppress the poverty rate contained in Deli Serdang District of $4.56 \%$ (https://deliserdangkab.bps.go.id/linkTabelStatis/view/id/36)

Duck is a type of poultry that many benefits start from the eggs until the meat is sold at a price higher than chicken meat. Duck feed is also not difficult to obtain and widely available in agriculture and plantation areas such as golden snails, tubers, and other greenery. But the farmers still not much use it in addition to less understanding of the technique, as well as in do his business.

Villagers in Desa Kolam have a small proportion to maintain ducks as their livelihoods in which their products are produced to meet daily needs. But these ducks are not managed optimally so that the revenue is also not maximal. This is seen from the number of ducks that are not much and egg production is not maximal.

Therefore, it is necessary to provide training and counseling to villagers to provide knowledge in planning their business, especially ducklings to improve the welfare of rural communities. If we see, villagers in Desa Kolam better understand how to raise ducks from feeding, taking care, and developing livestock. But the problems faced by 
the village community are in financial management and entrepreneurship. Financial management starts from the financial planning in which the calculation of the costs incurred to finance animal feed, the cost of building the cage, caring for livestock, and the cost incurred. Then the income earned from the sale of livestock products such as eggs or ducks that are sold then compared so as to obtain profits or losses from their business. While in entrepreneurship, people only sell products from ducks to agents so that agents can monopolize prices that cause harm to the community. Marketing technique is an important factor in making the network in product sales so eggs can be sold quickly and the selling price also does not fall. The importance of financial management and entrepreneurship aims to enable the public to determine a reasonable selling price for duck products so that people do not lose. Many people who previously breeding ducks do not continue its business due to loss because of the price of the expensive feed while the selling price of duck eggs that fall.

Another factor that led to lack of public knowledge about financial management and entrepreneurship that makes people can not plan and develop their business. Therefore, the dedication to the community through the provision of training and counseling on financial management and entrepreneurship is expected to improve the ability and develop duck farmers in Desa Kolam which ultimately improve the welfare of surrounding communities. The college as a facilitator overcomes the problem by providing training and counseling through educators and students in transferring knowledge to the community about financial management and farmer's entrepreneurship that ultimately increase the income and welfare of farmers in Desa Kolam, sub district of Percut Sei Tuan, Deli Serdang district, Province of North Sumatera.

\section{MATERIALS AND METHODS}

The main problem is the lack of knowledge of farmers about the calculation of expenditure and acceptance that occurred and knowledge of entrepreneurship for farmers. This problem is related to skill and knowledge of farmers about the methods or ways in financial planning both record and make a report up to do the marketing of the product. The materials used are presentations delivered in front of the forum and simulation of financial planning calculations so that farmers can better understand the process of financial planning. The method of delivery by way of exposure and discussion so that the discussion participants can understand the process of financial planning and entrepreneurship. The stages are:

a. The team makes presentations in front of the forum about concepts in general and the importance of financial planning and entrepreneurial knowledge.

b. Provides simulations of financial planning calculations.

c. Allow time for forums to ask about the less understood in financial planning and entrepreneurship.

\section{RESULTS AND DISCUSSION}

\section{Training and Counseling of Financial Management and Entrepreneurship}

On presentasion of topics on financial management and entrepreneurship, the team coordinates, especially, experts in the field of economics to convey the process of financial management and entrepreneurship. Speakers convey the process of financial planning that begins by creating a budget for expenditure. Budget preparation for expenditure aims to ensure that farmers know the amount of expenditure to be spent especially on feed and livestock and cattle care. The purpose of making expenditure to limit the cost incurred costs that do not provide benefits to farmers and a large burden. Planning cash receipts made to determine the amount of cashflow that will occur in the company so that will be known the company experienced a profit or loss.

In the training, people are still confused and can not accept the way of financial planning and entrepreneurship. This is because the understanding of people who still can not plan financially well and the need for supporting facilities such as notes or technology that help farmers in building a system in planning.

In this training and counseling, lecturers and students use a simple approach that is easily understood by the community so that people can easily understand in doing financial planning and entrepreneurship. One of them is in recording where a simple form is provided to record all accumulated expenditures that can be summed up at the end of the week as a whole and at the end of the month can be dated. While recording receipts are done every day that cumulative at the end of the month. At the end of the month all revenues and expenditures are subtracted and subtracted so that the amount of profit or loss obtained by the breeder is known. In addition, in determining the selling price of the product through the amount of expenditure issued each week then added to the desired profit level and divided by the number of eggs produced so as to obtain a reasonable price to be sold in the market. The following forms a simple recording form for acceptance and expenditure made on training and counseling on duck farmers in Desa Kolam sub district of Percut Sei Tuan. 


\section{Table 1 Income Sheet}

Week:

Name of Bussiness

Period of..

(in idr/ Rupiah)

\begin{tabular}{|c|c|c|c|c|c|}
\hline No & $\begin{array}{c}\text { Tanggal/ } \\
\text { Date }\end{array}$ & Produk/ Product & $\begin{array}{l}\text { Harga/ Unit } \\
\text { Price/ Unit }\end{array}$ & Jumlah/ Amount & Catatan/ Notes \\
\hline 1 & & & & & \\
\hline ? & & & & & \\
\hline 2 & & & & & \\
\hline 3 & & & & & \\
\hline & & & & & \\
\hline 4 & & & & & \\
\hline 5 & & & & & \\
\hline$J$ & & & & & \\
\hline Total & & & & & \\
\hline
\end{tabular}

Above sheet it appears that breeders only record the type and number of products sold each day accompanied by the income earned. The description column serves to record additional information such as broken eggs and more. Form is made every week so that at the end of the month will be known the total income obtained then compared with the expenditure so it is known the amount of income received.

Table 2 Expense Sheet

Week:

\section{Name of Bussiness}

Period of

(in idr/ Rupiah)

\begin{tabular}{|c|c|c|c|c|c|}
\hline \multirow{2}{*}{ No } & $\begin{array}{c}\text { Tanggal/ } \\
\text { Date }\end{array}$ & $\begin{array}{c}\text { Beban/ } \\
\text { Expense }\end{array}$ & $\begin{array}{c}\text { Jumlah Unit/ } \\
\text { Amount }\end{array}$ & $\begin{array}{c}\text { Total/ } \\
\text { Total }\end{array}$ & $\begin{array}{c}\text { Catatan/ } \\
\text { Notes }\end{array}$ \\
\hline \multirow{2}{*}{2} & & & & & \\
\hline & & & & & \\
\hline \multirow{2}{*}{3} & & & & & \\
\hline & & & & & \\
\hline \multirow{2}{*}{5} & & & & & \\
\hline & & & & & \\
\hline \multirow{2}{*}{ Total } & & & & & \\
\hline
\end{tabular}

In table 2 above is an example of a simple expenditure form in which there are types of expenditures incurred such as the purchase of fodder, cage care, livestock care or other expenses associated with livestock. In the end will be known the amount of expenses that farmers do each month. At the end of the month all expenditures for livestock are accumulated and compared to receipts so it is known how much profit or loss is received. Here is an example form of development planning. 
Table 3 Development Planning

\begin{tabular}{|c|c|c|c|c|c|c|}
\hline \multirow[t]{2}{*}{ No } & \multirow{2}{*}{ Deskripsi/ Description } & \multicolumn{2}{|c|}{ Detail } & \multicolumn{2}{|c|}{ Expected Completion Date } & \multirow{2}{*}{ Notes } \\
\hline & & Name & Quantity & Started & Finished & \\
\hline & & & & & & \\
\hline & & & & & & \\
\hline & & & & & & \\
\hline & & & & & & \\
\hline & & & & & & \\
\hline & & & & & & \\
\hline & & & & & & \\
\hline & & & & & & \\
\hline & & & & & & \\
\hline & Total & & & & & \\
\hline
\end{tabular}

From table 3 above looks planning that will be done farmers fore. The goal is that farmers can calculate the initial cost to be expended to develop its business which in the end breeders can start to set aside his finances to expand his business.

In the field of entrepreneurship, the team provides counseling about the techniques of marketing so that the product can be known to the public and expand its marketing area. In general there are three simple marketing techniques: partnerships, direct sales, and through agents. In partnership, the community builds a network where the farmer can sell to the parties who need the eggs directly without going through the agent that harms the farmer due to the unstable price. The second technique is through direct sales where farmers can sell directly to the community so that people buy eggs much cheaper. Third is through an agency where breeders can sell directly these duck products without having to find the party who bought the egg or duck. This third technique will have an impact on the selling price where the agent will monopolize the purchase price so that it can harm the farmer.

From the results of counseling and training that livestock groups began to know the importance of financial management that begins with financial planning. This is related to expenditures that will occur by farmers. In addition, the entrepreneurship outreach described ways to grow the business to become better starting with an increase in the number of assets, marketing and including financial planning in developing its business. The result is in this entrepreneurial extension that farmers begin to plan their business development from building cages, increasing the number of ducks, and expanding the marketing area. With so expected increase in economy and welfare breeder increase.

\section{CONCLUSION AND IMPLICATION}

The conclusion of this activity is the community especially duck breeders can further increase their livestock especially in terms of financial management and entrepreneurship, breeders have started to calculate planning forward and expand their business and marketing. The importance in financial planning for breeders as well as doing good marketing aims to increase income and expand its business becomes larger. As for the implications of this activity, farmers should record revenue and expense that aim to take into account the progress of the livestock business. Besides that, it is used in developing its business so that it can be more developed. Suggestions to farmers further expand the marketing area as well as product variations so that not only focus on the sale of raw eggs.

\section{REFERENCES}

Direktorat Riset dan Pengabdian kepada Masyarakat. 2017. Panduan Pelaksanaan Penelitian dan Pengabdian Kepada Masyarakat di Perguruan Tinggi Edisi XI Tahun 2017. Direktorat Riset dan Pengabdian kepada Masyarakat, Direktorat Jenderal Penguatan Riset dan Pengembangan, Kementerian Riset, Teknologi, dan Pendidikan Tinggi. Jakarta.

LPM Unimed. 2017. Panduan Pengajuan Program Pengabdian Kepada Masyarakat Sumber Dana BOPTN dan Mandiri Tahun 2017. Lembaga Pengabdian Kepada Masyarakat Universitas Negeri Medan. Medan 